\title{
Organotypical tissue cultures from adult murine colon as an in vitro model of intestinal mucosa
}

\author{
Petra M. Bareiss · Marco Metzger · Kai Sohn · Steffen Rupp • \\ Julia S. Frick · Ingo B. Autenrieth · Florian Lang • \\ Heinz Schwarz • Thomas Skutella $\cdot$ Lothar Just
}

Accepted: 15 February 2008 / Published online: 5 March 2008

(C) Springer-Verlag 2008

\begin{abstract}
Together with animal experiments, organotypical cell cultures are important models for analyzing cellular interactions of the mucosal epithelium and pathogenic mechanisms in the gastrointestinal tract. Here, we introduce a three-dimensional culture model from the adult mouse colon for cell biological investigations in an in vivo-like environment. These explant cultures were cultured for up to 2 weeks and maintained typical characteristics of the intestinal mucosa, including a high-prismatic epithelium with specific epithelial cell-to-cell connections, a basal lamina and
\end{abstract}

P. M. Bareiss $\cdot$ T. Skutella $\cdot$ L. Just $(\bowtie)$

Institute of Anatomy,

Center for Regenerative Biology and Medicine,

Eberhardt-Karls-University Tuebingen,

Oesterbergstrasse 3, 72074 Tuebingen, Germany

e-mail: ljust@anatom.uni-tuebingen.de

\section{Metzger}

Institute of Child Health, Neural Development Unit, University College London, 30 Guilford Street,

London WC1N1EH, UK

K. Sohn $\cdot$ S. Rupp

Fraunhofer-Institut fuer Grenzflaechen- und

Bioverfahrenstechnik, Nobelstr. 12,

70569 Stuttgart, Germany

J. S. Frick · I. B. Autenrieth

Institute of Medical Microbiology and Hygiene,

University of Tuebingen, Elfriede-Aulhorn-Strasse 6,

72076 Tuebingen, Germany

F. Lang

Department of Physiology, University of Tuebingen,

Gmelinstrasse 5, 72076 Tuebingen, Germany

H. Schwarz

Max-Planck-Institute for Developmental Biology,

Spemannstrasse 35, 72076 Tuebingen, Germany various connective tissue cell types, as analyzed with immunohistological and electron microscopic methods. The function of the epithelium was tested by treating the cultures with dexamethasone, which resulted in a strong upregulation of the serum- and glucocorticoid-inducible kinase 1 similar to that found in vivo. The culture system was investigated in infection experiments with the fungal pathogen Candida albicans. Wildtype but not $\Delta \mathrm{cph} 1 / \Delta \mathrm{efg} 1-\mathrm{knockout}$ Candida adhered to, penetrated and infiltrated the epithelial barrier. The results demonstrate the potential usefulness of this intestinal in vitro model for studying epithelial cell-cell interactions, cellular signaling and microbiological infections in a three-dimensional cell arrangement.

Keywords In vitro model $\cdot$ Intestine $\cdot$ Serum- and glucocorticoid-inducible kinase $1 \cdot$ Dexamethasone Infection · Candida albicans

\section{Introduction}

The intestinal mucosal epithelium acts as a cellular barrier between the gut and the intestinal lumen, controlling the passage of ions, molecules and microorganisms. Both this barrier function and epithelial turnover are strongly dependent on paracrine and exogenous factors, on extracellular matrix compounds and on the epithelial-mesenchymal cell-cell interaction in the intestinal mucosa. A number of primary gastrointestinal diseases such as autoimmune enteropathies and microbiological infections result in damage to this highly organized epithelial barrier (for reviews see Heyman 2005; Rowlands et al. 1999).

In addition to animal experiments, intestinal cell cultures are important models for investigating the function of epithelial cells of the intestinal mucosa under normal and 
pathological conditions. Because of the complex threedimensional cellular interactions and heterogeneity of mucosal cells in vivo, there are methodical limitations to the use of monolayer in vitro models and cultures with tumor cell lines. For this reason, three-dimensional primary tissue cultures, which are more representative of the in vivo environment, have certain advantages for studies in physiology, pharmacology, developmental biology, tumor biology, or microbiology (Howdle 1983; Trier 1976).

Long-term, three-dimensional intestinal cell and tissue cultures from different species have been widely used in basic research, particularly since the seventh decade of the last century (mouse (Defries and Franks 1977), rat (Altmann and Quaroni 1990; Shamsuddin et al. 1978), man (Autrup 1980; Menard and Arsenault 1987), chicken (Mothes et al. 1985) and hamster (Schiff 1975)). Interestingly, these complex in vitro models are now undergoing a renaissance in combination with new analytical methods and again play an increasing role in intestinal research, including investigations of epithelial homeostasis, cellular differentiation and organization (Abud et al. 2005; Quinlan et al. 2006). However, only a few groups have worked with adult intestinal tissue (Autrup et al. 1978a, b; Defries and Franks 1977; Finney et al. 1986; Moorghen et al. 1996; Shamsuddin et al. 1978).

In the present study, we established an organotypical explant culture of adult mouse colon that allowed the investigation of cellular interactions in a three-dimensional cell arrangement. We analyzed this in vitro model using immunohistochemistry, in situ hybridization and electron microscopy.

Two types of experiments were performed to validate the cultivation system. First, the influence of dexamethasone on the gene expression of the serum- and glucocorticoid-inducible kinase 1 (SGK1) in the cultures was compared with respective in vivo experiments (Lang et al. 2006). The SGK1 plays an important role in the activation of ion channels located in apical membranes of epithelial cells, especially in the lung, kidney and gut. Expression of the kinase is known to be upregulated by glucocorticoids (Firestone et al. 2003) and in inflammatory bowel disease (Waldegger et al. 1999).

Second, we verified the quality of the epithelial barrier in the tissue culture by means of in vitro infection with Candida albicans. This fungus is an opportunistic human pathogen usually found on the skin and on the mucosa of the gut, oral cavity and vaginal canal and can lead to deeply seated systemic infections (Darouiche 1998; Defries and Franks 1977).

\section{Materials and methods}

\section{Animals}

The animal experiments were conducted in accordance with local guidelines for the ethical use of animals in research at the University of Tuebingen, which conform to international guidelines. Adult male C57/BL6 mice were sacrificed by carbon dioxide inhalation for histological analysis and tissue culture experiments.

\section{Organotypical tissue cultures}

Tissue cultures were prepared from the murine descending colon, which was opened along its length and cleaned of fecal contents in cold HBSS containing penicillin (100 U/ $\mathrm{ml}$, PAA, Pasching, Austria), streptomycin $(100 \mu \mathrm{g} / \mathrm{ml}$, PAA) and metronidazole $(50 \mu \mathrm{g} / \mathrm{ml}$, Fresenius Kabi Deutschland GmbH, Bad Homburg, Germany). The gut was cut into $2 \mathrm{~mm}^{2}$ pieces and transferred onto uncoated membrane inserts (Millipore CM, $0.4 \mu \mathrm{m}$ pore size, Millipore, Eschborn, Germany), which were positioned in the respective well of a six-well plate. To each well, $1 \mathrm{ml}$ medium was added consisting of HEPES buffered DMEM/F12 (PAA), $10 \%$ adult horse serum (Invitrogen, Karlsruhe, Germany), penicillin $(100 \mathrm{U} / \mathrm{ml}$, PAA), streptomycin $(100 \mu \mathrm{g} / \mathrm{ml}$, PAA), L-glutamine (2 mM, PAA), insulin/transferrin/selenite mix (1:100, Invitrogen), Albumax $(1 \mathrm{mg} / \mathrm{ml}$, Invitrogen), hydrocortisone $(1 \mu \mathrm{M}$, Sigma, Frickenhausen, Germany), glucagon (14.3 nM, Sigma), 3,3',5'-triiodo-Lthyronine (1 nM, Sigma), ascorbate-2-phosphate $(200 \mu \mathrm{M}$, Sigma), linoleic acid (20 $\mu \mathrm{M}$, Sigma), estradiol (10 nM, Sigma) and keratinocyte growth factor (50 ng/ml, Sigma). The tissue cultures were incubated in a humidified incubator at $37^{\circ} \mathrm{C}$ and $5 \% \mathrm{CO}_{2}$ for up to two weeks. The culture medium was renewed every 2 days.

Immunohistochemistry

Immunohistochemistry was performed on $5 \mu \mathrm{m}$ thick paraffin sections. After deparaffinization and rehydration, the sections were pretreated by either boiling in citrate buffer (10 mM, Sigma, pH 6.0) for $10 \mathrm{~min}$ or incubating in pronase solution $(1 \mathrm{mg} / \mathrm{ml}$ pronase, Merck, Darmstadt, Germany; $9 \mathrm{mM} \mathrm{CaCl}_{2}$ in Tris buffer (TBS, $25 \mathrm{mM}$ Trizma base, $140 \mathrm{mM} \mathrm{NaCl}, \mathrm{pH} 7.4)$ ) at $37^{\circ} \mathrm{C}$ for $5 \mathrm{~min}$. After three washes with TBS for $5 \mathrm{~min}$, the sections were blocked with TBS containing $0.1 \%$ bovine serum albumin, $10 \%$ swine serum and $0.3 \%$ Triton ${ }^{\circledR} \mathrm{X}-100$ for 30 min. Incubation with primary antibodies was performed overnight at $4{ }^{\circ} \mathrm{C}$. The following primary antibodies were used: mouse anti-bromodeoxyuridine (BrdU; 1:100, Dako, Hamburg, Germany), rabbit anti-cytokeratin (wide spectrum, 1:500, Dako), rabbit antiGFAP (1:600, Dako), rabbit anti-laminin (1:50, MP Biomedicals, Illkirch, France), rabbit anti-smooth muscle actin (1:400, AMS Biotechnology, Wiesbaden, Germany), and mouse anti- $\beta$-tubulin III (TuJ-1, 1:500; Covance, Richmond, USA). After three washes with TBS, the sections were incubated with DAPI solution ( $200 \mathrm{ng} / \mathrm{ml}$, Invitrogen) and fluo- 
rochrome-linked secondary antibodies (1:400, goat antirabbit IgG, Cy3 or goat anti-mouse $\mathrm{IgG}, \mathrm{Cy} 3$; Invitrogen) for $30 \mathrm{~min}$ at room temperature. They were then washed three more times for 5 min with TBS, briefly rinsed in distilled water, dried, and covered with Kaiser's gelatine solution (Merck). Goblet cells were stained with Alcian blue staining, as described by Romeis (Romeis 1968). Alkaline phosphatase activity was visualized by incubation of cryosections with freshly prepared substrate solution (nitroblue tetrazolium salt and 5-bromo-4-chloro-3-indolyl phosphate (Roche) in Tris buffer $\mathrm{pH} 9.5$ ).

\section{BrdU labeling}

BrdU $(10 \mu \mathrm{M})$ was added to the culture medium of proliferating cultures for $24 \mathrm{~h}$. Thereafter, tissue cultures were immediately fixed. Detection of BrdU-labeled cells was carried out by immunohistochemistry.

\section{In situ hybridization for SGK1}

For in situ hybridization, frozen colon samples and tissue cultures were cut into $10 \mu \mathrm{m}$ thick slices with a freezing microtome. The sections were then mounted on Superfrost Plus slides (Langenbrinck, Emmendingen, Germany), dried at $60^{\circ} \mathrm{C}$ for $30 \mathrm{~s}$ and fixed with $4 \%$ phosphate-buffered paraformaldehyde for $20 \mathrm{~min}$. After 3 washes with phosphate-buffered saline (PBS, $0.1 \mathrm{M}, \mathrm{pH}$ 7.4), the slides were incubated with TE buffer (100 mM Tris, $50 \mathrm{mM}$ EDTA, pH 8) containing $2 \mu \mathrm{g} / \mathrm{ml}$ proteinase $\mathrm{K}$ (Sigma) for $10 \mathrm{~min}$ at room temperature and rinsed again three times with PBS. In order to reduce nonspecific background, the slides were acetylated twice for $5 \mathrm{~min}$ with TEA buffer $(0.1 \mathrm{M}$ triethanolamine, $\mathrm{pH} 8.0$ ) containing $0.25 \%$ (v/v) acetic anhydride (Sigma). After pre-hybridization with hybridization buffer (50\% formamide (Sigma), $10 \%$ dextran sulfate, $5 \mathrm{mM}$ EDTA, $20 \mathrm{mM}$ Tris pH 8, $10 \mathrm{mM}$ DTT, 1x Denhardt's solution, $0.05 \%$ tRNA, $300 \mathrm{mM} \mathrm{NaCl}$ ) for $1 \mathrm{~h}$ at $63^{\circ} \mathrm{C}$, the sections were incubated overnight at $63^{\circ} \mathrm{C}$ with fresh hybridization buffer containing the denatured DIG-labeled sense or antisense probe (200 $\mathrm{ng} / \mathrm{ml})$. DIG-labeled, SGK-1specific, antisense and sense RNA probes were generated by in vitro transcription with a DIG-labeling kit (Roche, Mannheim, Germany). The SGK1 plasmid (pPCRScript, Stratagene, Germany) containing the murine SGK1 sequence (position 20-1373) was kindly provided by Dr. K. Klingel. For in vitro transcription, the plasmid was linearized with NotI (antisense probe) or with SalI (sense probe). To enhance penetration into the tissue sections, the probes were alkali hydrolyzed to an average length of 400 bases. After hybridization, the slides were briefly rinsed in $2 \times$ $\mathrm{SSC}$ at $63^{\circ} \mathrm{C}$ and then 3 times in $0.1 \times \mathrm{SSC}$ for $15 \mathrm{~min}$ at $63^{\circ} \mathrm{C}$. Detection of DIG-labeled RNA probe was performed according to the protocol of the DIG nucleic acid detection kit (Roche, Basel Switzerland). The tissues were blocked for $30 \mathrm{~min}$ with blocking buffer $(1 \%$ blocking reagent (Roche) in maleic acid buffer (0.1 M maleic acid, $0.15 \mathrm{M}$ $\mathrm{NaCl}, \mathrm{pH} 7.5)$ ) and then incubated with alkaline phosphatase-conjugated antibody solution (anti-DIG antibody (1:2500 Roche) in blocking buffer containing $0.1 \%$ Triton $^{\circledR}$ $\mathrm{X}-100$ ) for $1 \mathrm{~h}$. Following four washes with maleic acid buffer for $15 \mathrm{~min}$, the slides were equilibrated for $5 \mathrm{~min}$ in Tris buffer pH 9.5 (0.1 M Tris, $\mathrm{pH} 9.5,0.1 \mathrm{M} \mathrm{NaCl}, 50 \mathrm{mM}$ $\mathrm{MgCl}_{2}$ ). Color development was carried out with freshly prepared substrate solution (nitroblue tetrazolium salt and 5-bromo-4-chloro-3-indolyl phosphate (Roche) in Tris buffer $\mathrm{pH}$ 9.5). After three washes with PBS, the slides were rinsed in distilled water, dried and coverslipped with Kaiser's gelatine solution.

\section{Electron microscopy}

Cultures were fixed with $2 \%$ glutaraldehyde (Sigma) and $5 \%$ paraformaldehyde (Sigma) in HEPES buffer $(100 \mathrm{mM}$ HEPES, $90 \mathrm{mM}$ saccharose, $10 \mathrm{mM} \mathrm{MgCl}_{2}, 10 \mathrm{mM} \mathrm{CaCl}_{2}$, $\mathrm{pH} 7.0$ ) at $4^{\circ} \mathrm{C}$ for $2 \mathrm{~h}$. Samples were postfixed with $1 \%$ osmium tetroxide in $100 \mathrm{mM}$ phosphate buffer $\mathrm{pH} 7.2$ for $1 \mathrm{~h}$ on ice, washed with $\mathrm{H}_{2} \mathrm{O}$, treated with $1 \%$ aqueous uranyl acetate for $1 \mathrm{~h}$ at $4{ }^{\circ} \mathrm{C}$, dehydrated in a graded series of ethanol, infiltrated with ethanol/resin mixtures and finally embedded in Epon (using glycidether 100 from Roth, Karlsruhe, Germany). Ultrathin sections were stained with uranyl acetate and lead citrate (Venable and Coggeshall 1965) and viewed under a Philips CM10 electron microscope at $60 \mathrm{kV}$ using a $30 \mu \mathrm{m}$ objective aperture.

Pharmacological treatment

SGK1 expression was analyzed by treating adult mice and tissue cultures with dexamethasone. Animals were injected with dexamethasone phosphate disodium salt (dissolved in $0.9 \%$ saline, Sigma) at a dose of $10 \mu \mathrm{g} / \mathrm{g}$ body weight for $8 \mathrm{~h}$. Mice injected only with $0.9 \%$ saline served as controls.

Cultures were treated with $100 \mathrm{nM}$ dexamethasone for $8 \mathrm{~h}$ after 14 days of cultivation in vitro.

\section{Infection experiments with Candida albicans}

The Candida strains used in this study were Candida 14 (clinical isolate Sc5314) and Candida 34 (cphl::hisG/ cph1::hisG, efg1::hisG/efg1::hisG::URA3::hisG) (Dieterich et al. 2002). The strains were cultured overnight at $30^{\circ} \mathrm{C}$ in YPD (yeast extract/peptone/dextrose) medium containing 2\% glucose (Difco, BD Heidelberg, Germany) from plated cultures onto YPD agar plates (2\%; Bacto Agar, Difco) as described previously (Dieterich et al. 2002). 
Infection experiments were performed in the absence of antibiotics. Thousand cells in $1 \mu \mathrm{l}$ YPD medium with $0.1 \mathrm{mM}$ uridine were pipetted onto each organotypical tissue culture that was cultured for 10 days as described above. After 8 or $24 \mathrm{~h}$, the cultures were fixed with $4 \%$ formaldehyde (Sigma) in PBS and embedded in paraffin. For Candida staining, the Grocott staining protocol was carried out on $5 \mu \mathrm{m}$ thick paraffin sections (Grocott 1955).

\section{Results}

Three-dimensional tissue culture

Three-dimensional tissue samples of adult mouse colon were cultured on membrane inserts for up to 4 weeks
(Fig. 1a, d). After 3 days in vitro, the main part of the epithelium had degenerated and was subsequently completely renewed. After this epithelial reorganization, a high-prismatic epithelium covered the surface of the tissue culture and formed crypt-like structures (Fig. 1a-c). Within the first 6 days of cultivation, half the explants exhibited good tissue preservation as shown by an epithelium-specific surface structure of the tissue culture. At this time point, a number of proliferating epithelial cells could be identified by BrdU proliferation assay (Fig. 2c). Between the third and fourth week in culture, the quality of epithelial cell formation decreased due to the reduced regeneration capacity of the epithelium and a loss of epithelial cells. At this time, no BrdU-positive cells could be detected in the epithelium (data not shown). For this reason, we only used explants cultured between 6 and 14 days for further analysis. Immunohistochemical
Fig. 1 Histological characterization of intestinal tissue cultures by hematoxylin (a-d), alkaline phophatase histochemistry (e), and Alcian blue staining (f). a Overview of a paraffin cross-section from culture after 6 days in vitro. The culture possessed a high-prismatic epithelium (Ep) with crypt-like structures (arrows), connective tissue (CT) and smooth muscle structures (M). b, c Higher magnification of $\mathbf{a}$. The arrows point to crypt-like structures of the epithelium. d Higher magnification of a from the lower part of culture. The arrows indicate the lower surface of the culture above the micromembrane. e Apical alkaline phophatase activity demonstrates the polarity of the enterocytes (arrows). The broken line denotes the border of the epithelial cells. f Detailed view of high-prismatic enterocytes and Alcian bluestained goblet cells (arrows) from tissue cultured for 9 days. The broken line marks the bordering epithelium. Scale bar $100 \mu \mathrm{m}$ in $\mathbf{a} ; 50 \mu \mathrm{m}$ in $\mathbf{b} ; 20 \mu \mathrm{m}$ in $\mathbf{c}, \mathbf{d}, \mathbf{e}$ and $10 \mu \mathrm{m}$ in $\mathbf{f}$
A
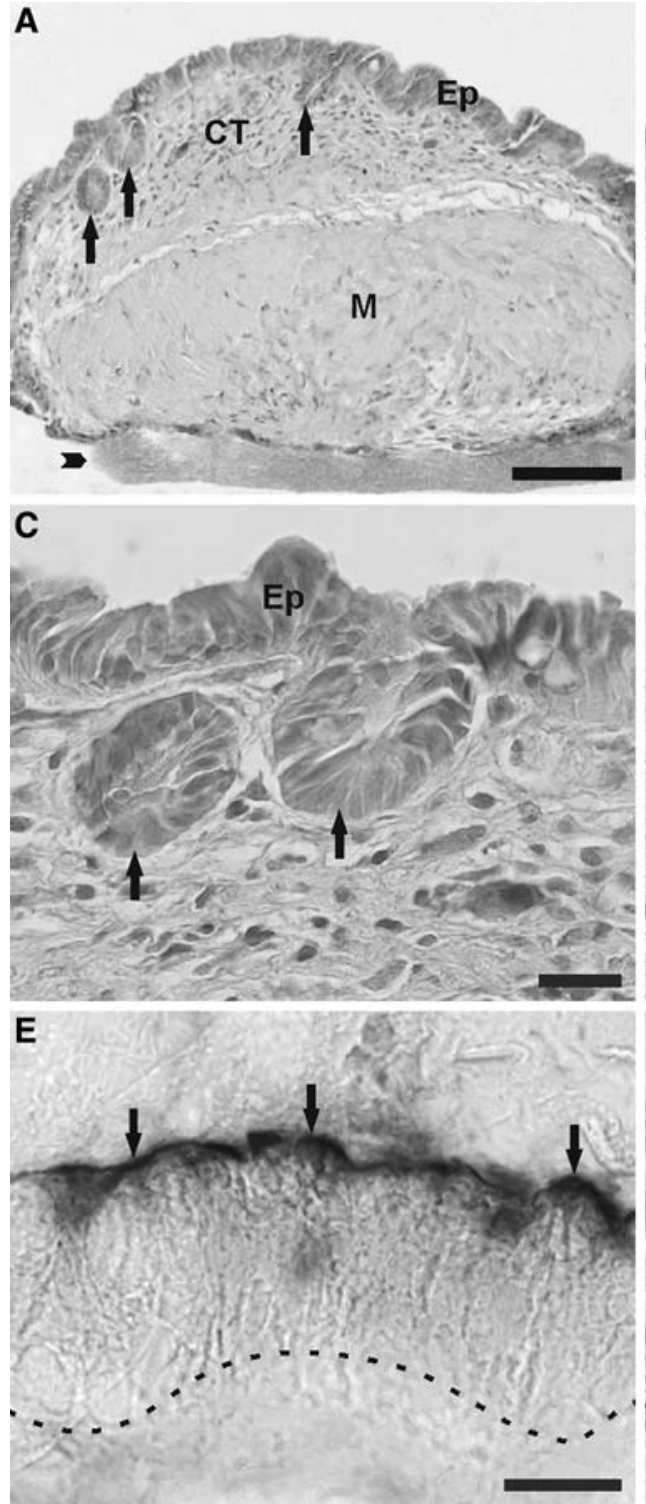

B
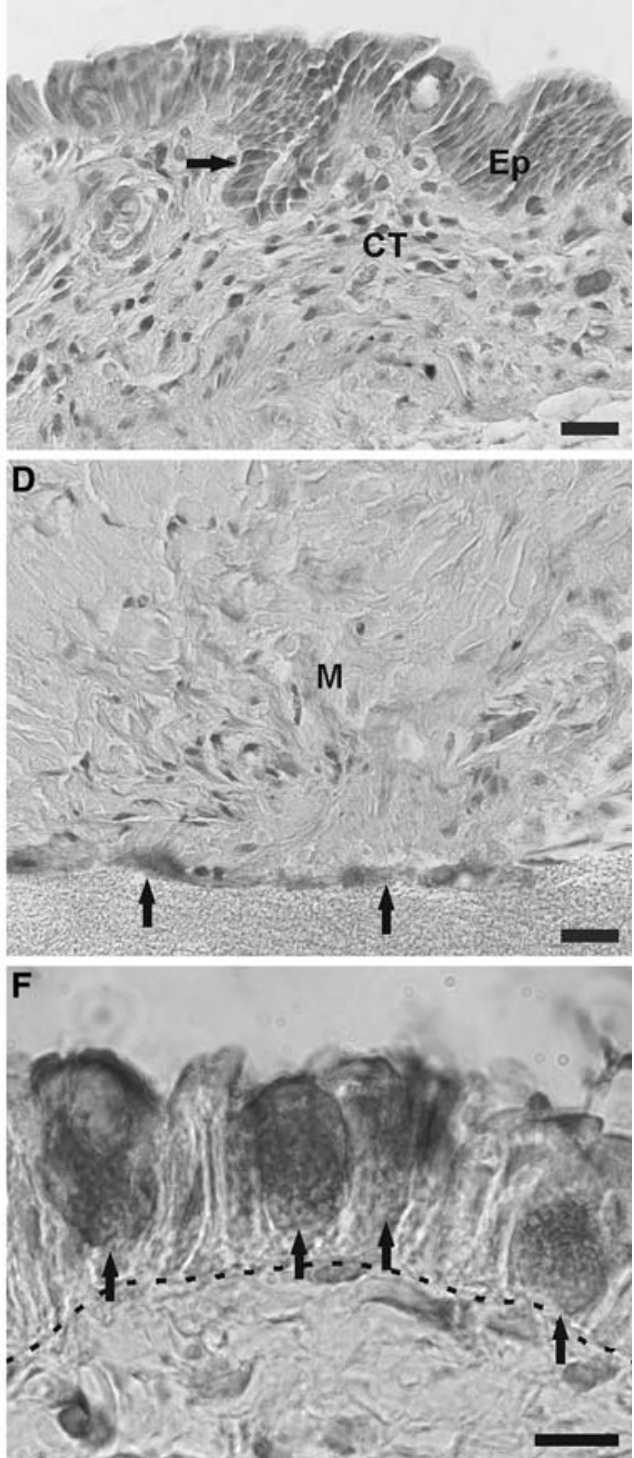

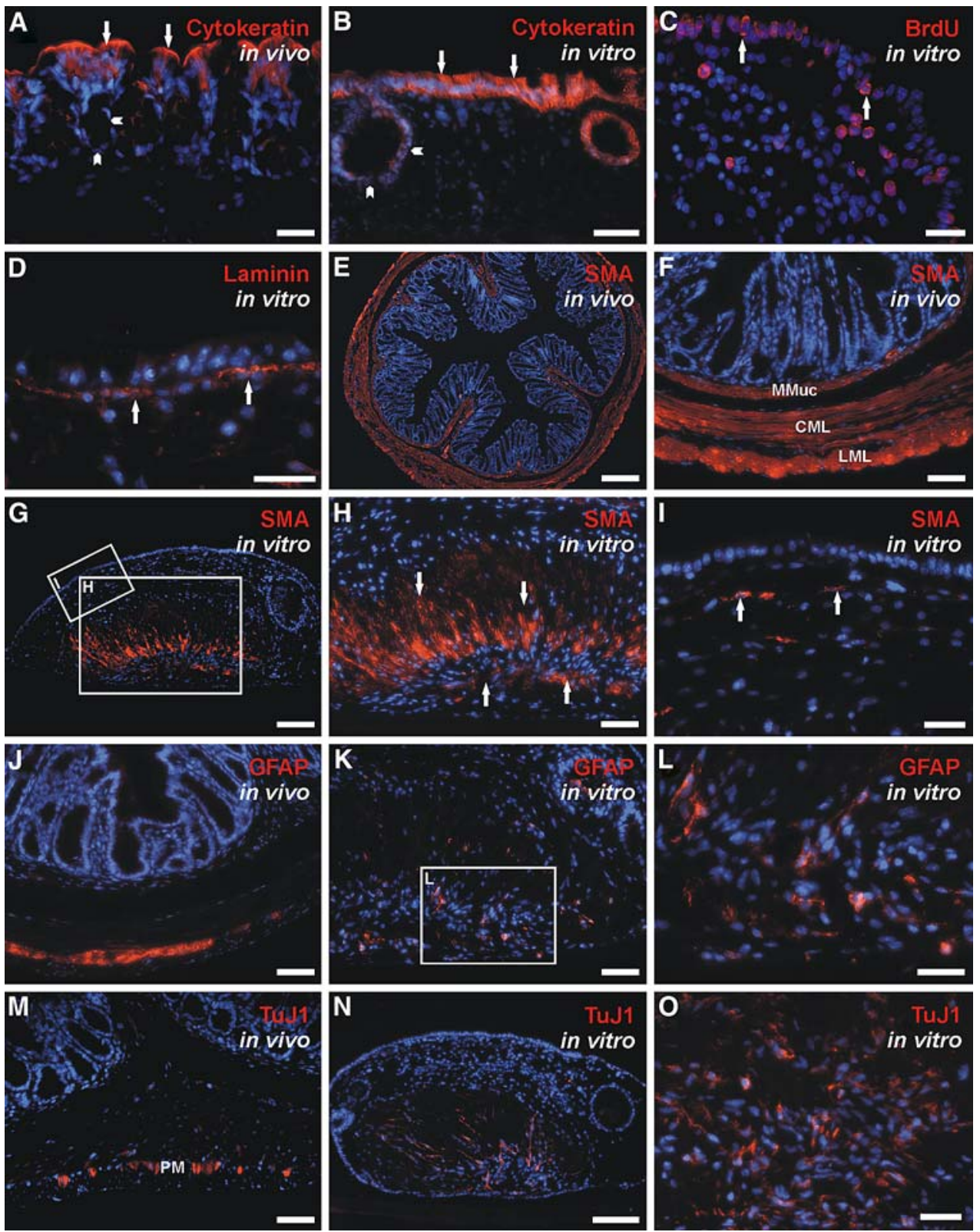

Fig. 2 Immunohistological characterization of colonic tissue cultures in comparison to adult mouse gut. $\mathbf{a}, \mathbf{b}$ Cytokeratin immunofluorescence of epithelial cells on paraffin sections from adult mouse colon $(\mathrm{red}, \mathbf{a})$ and from tissue culture (red, b); DAPI (blue). The arrows point to strongly stained, differentiated epithelial cells. In contrast, undifferentiated cells showed only weak staining (arrowheads). c Proliferating epithelial cells could be detected by immunohistochemistry against BrdU (red) after 6 days in vitro; DAPI (blue). The arrows point to proliferating epithelial cells. d Laminin immunofluorescence on cryosections from tissue culture. The arrows indicate the laminin-positive basal membrane. e-i Smooth muscle actin (SMA) immunofluorescence of smooth muscle cells on sections from adult mouse colon ( $\mathrm{red} ; \mathbf{e}, \mathbf{f})$ and tissue cultures ( $r e d ; \mathbf{g}-\mathbf{i}$ ); DAPI (blue). In paraffin sections of adult mouse colon, the longitudinal muscle layer (LML), the circular muscle layer

characterization of tissue cultures were performed in comparison to native mouse gut (Fig. 2). Epithelial cells were immunostained for cytokeratin (Fig. 2b). Alkaline phospha-
(CML) and the mucosal muscle layer (MMuc) stained positive (e, f). e Overview. $\mathbf{f}$ Higher magnification of $\mathbf{e}$. In the in vitro model, the majority of the positively stained cells (arrows) were found in the lower part of the culture $\mathbf{g}, \mathbf{h} . \mathbf{g}$ Overview of tissue culture. $\mathbf{h}$ Higher magnification of g. i Isolated positively marked smooth muscle cells (arrows) could also be observed in the upper part of the culture. $\mathbf{j}-\mathbf{I}$ Immunofluorescence staining of glial fibrillary acidic protein (GFAP)-expressing glial cells in adult mouse colon $(\mathrm{red} ; \mathbf{j})$ and tissue culture of adult mouse colon ( red; $\mathbf{k}, \mathbf{l}$ ); DAPI (blue). I higer magnification of $\mathbf{k} . \mathbf{m}-\mathbf{o} \beta$-tubulin III (TuJ1) immunofluorescence of neurons in vivo (red; $\mathbf{m})$ and in vitro (red; n, o); DAPI (blue). m TuJ1-expressing cells in the plexus myentericus (PM) of mouse adult colon. $\mathbf{n}$ Overview of tissue culture. $\mathbf{o}$ Higher magnification of TuJ1-positive cells. Scale bar $200 \mu \mathrm{m}$ in e; $100 \mu \mathrm{m}$ in $\mathbf{g ,} \mathbf{n} ; 50 \mu \mathrm{m}$ in $\mathbf{b}, \mathbf{f}, \mathbf{h}, \mathbf{j}, \mathbf{k}, \mathbf{m} ; 25 \mu \mathrm{m}$ in $\mathbf{a}, \mathbf{c}, \mathbf{d}, \mathbf{i}, \mathbf{l}, \mathbf{o}$

tase activity at the apical side of epithelial cells was detected by histochemistry (Fig. 1e). Differentiated goblet cells, in particular, could be shown by Alcian blue staining and trans- 
mission electron microscopy (Figs. 1f, 3d, e). The Lamininimmunopositive basal membrane indicated the border between epithelium and connective tissue (Fig. 2d). Transmission electron microscopic views identified microvilli structures at the apical surface of high-prismatic epithelial cells (Fig. 3a, b, f). Typical tight junctions and desmosomes of epithelial junction complex and a well-organized basal lamina could also be detected (Fig. 3b, c, f).

The connective tissue showed characteristic collagen fibers, fibroblasts (Fig. 3i, j) and smooth muscle cells (Fig. 3k). Immunohistochemistry for smooth muscle actin demonstrated a definite orientation of muscle cells mainly in the lower part of the tissue culture (Fig. $2 \mathrm{~g}-\mathrm{i}$ ). In addition, $\beta$-tubulin III-positive enteric neurons (Fig. $2 \mathrm{~m}-\mathrm{O}$ ) and GFAP-expressing glial cells (Fig. 2j-1) were visualized. Interestingly, some mast cell-like cells and lymphatic-like vessel structures could be detected by transmission electron microscopy (Fig. 3g-i).

In addition to the small crypt-like structures, large cystlike formations could also be observed. These cysts with an introverted epithelium developed inside the three-dimensional culture (Fig. 31-n).
Fig. 3 Characterization of adult colonic tissue culture by transmission electron microscopy. a Single layer of high-prismatic epithelium with an underlying myofibroblast. b Higher magnification of the epithelial cellcell-contact from a. Arrows point to the tight junction and the desmosome of the junctional complex. c Higher magnification of the basal membrane (arrows) from a. d, e The arrow indicates a goblet cell in the epithelium. f Microvilli are visible on the apical surface. g Lymphatic-like vessel in the connective tissue under the epithelial cell layer. Asterisk marks the lumen. $\mathbf{h}$ Higher magnification of $\mathbf{g}$. $\mathbf{i}$ Fibroblasts (arrow) and a few mast cell-like cells (arrowhead) in the connective tissue. $\mathbf{j}$ Higher magnification of i. Arrow points to a fibroblast-like cell. Asterisks indicate collagen fibers. k Muscle cells (arrows) from the lower part of the culture. 1 Hematoxylin and Alcian blue staining of a cyst-like structure showing a lumen L with dead cells. m Transmission electron microscopy of newly developing cyst in epithelium. $\mathbf{n}$ High magnification of a cyst-like structure. The arrows show microvilli of the cystic epithelium (CEp). Scale bar $20 \mu \mathrm{m}$ in $\mathbf{l}, 10 \mu \mathrm{m}$ in $\mathbf{g}, \mathbf{i}, \mathbf{k}, \mathbf{m} ; 5 \mu \mathrm{m}$ in $\mathbf{d , ~} \mathbf{h} ; 3 \mu \mathrm{m}$ in $\mathbf{a}, \mathbf{e}, \mathbf{f}, \mathbf{j} ; 1.5$ in $\mathbf{n}$; $1 \mu \mathrm{m}$ in $\mathbf{c} ; 0.5 \mu \mathrm{m}$ in $\mathbf{b}$
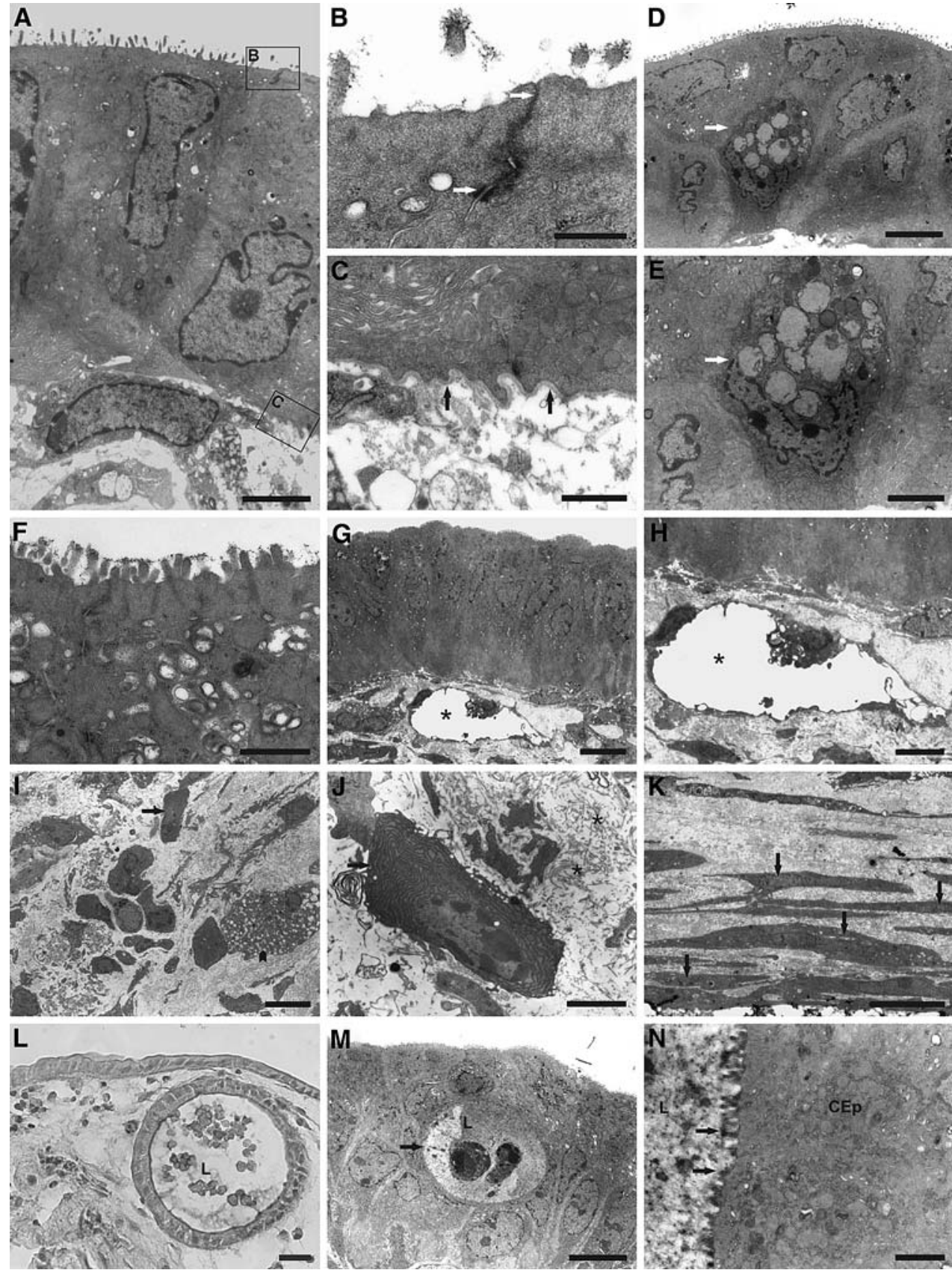
SGK1 mRNA expression in epithelial cells of tissue culture was strongly increased by dexamethasone similar to in vivo

In previous studies, we demonstrated that the treatment of mice with dexamethasone strongly increased the mRNA expression of SGK1 in the mucosal epithelium of the small intestine (Grahammer et al. 2006).

We evaluated the proposed in vitro model by testing whether the in vivo effect of dexamethasone was reproduced in our intestinal cultures. To do this, we analyzed the SGK1 mRNA expression by in situ hybridization on cryostat sections from adult murine colon and intestinal tissue cultures. Tissue cultures were incubated with $100 \mathrm{nM}$ dexamethasone for $8 \mathrm{~h}$. Animals were injected with dexamethasone phosphate disodium salt at a dose of $10 \mu \mathrm{g} / \mathrm{g}$ body weight for $8 \mathrm{~h}$. In the epithelium of both the adult mouse colon in vivo (Fig. 4b, e) and colonic tissue cultures in vitro (Fig. 4g, h), the application of dexamethasone strongly enhanced SGK1 mRNA expression compared to the untreated group (Fig. 4a, d, f). The sense control did not show any signals (Fig. 4c).

\section{Infection with Candida albicans}

Candida albicans occurs naturally in the gastrointestinal tract and can cause superficial infections. We used the organotypical tissue culture for the infection assay with two Candida strains. After 10 days in vitro, colonic tissue cultures were infected with the wildtype (Candida 14) or the

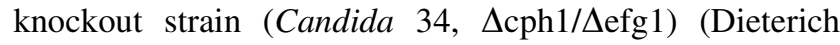
et al. 2002). The infection of the tissue cultures with wildtype Candida cells resulted in adhesion of the Candida cells after $8 \mathrm{~h}$ (Fig. 5e) with subsequent penetration and infiltration after $24 \mathrm{~h}$ of incubation (Fig. 5a-d). Candida strain Can 34 was not capable of adhering to the culture surface (Fig. 5i) or penetrating the epithelial barrier (Fig. 5f-h) of any of the analyzed explant cultures. These experiments indicate that this in vitro model could be of use
Fig. 4 Dexamethasone strongly increased the SGK-1 mRNA expression in epithelial cells in vivo and in vitro. In situ hybridization for SGK1 mRNA on cryostat sections from adult mouse colon a-e and tissue culture $\mathbf{f}-\mathbf{h}$. a Overview of SGK-1 mRNA expression in the colon of untreated mouse. b Overview of SGK-1 mRNA expression in the colon of dexamethasonetreated mouse. c Sense control. d Higher magnification of a. e Higher magnification of $\mathbf{b}$. $\mathbf{f}$ In situ hybridization for SGK1 mRNA expression in the epithelium of untreated tissue culture. g Increased SGK-1 expression after dexamethasone treatment. h Higher magnification of g. Arrows point to the mucosal epithelium of the tissue culture. Scale bar $100 \mu \mathrm{m}$ in a-e; $50 \mu \mathrm{m}$ in $\mathbf{g} ; 25 \mu \mathrm{m}$ in $\mathbf{f}, \mathbf{h}$
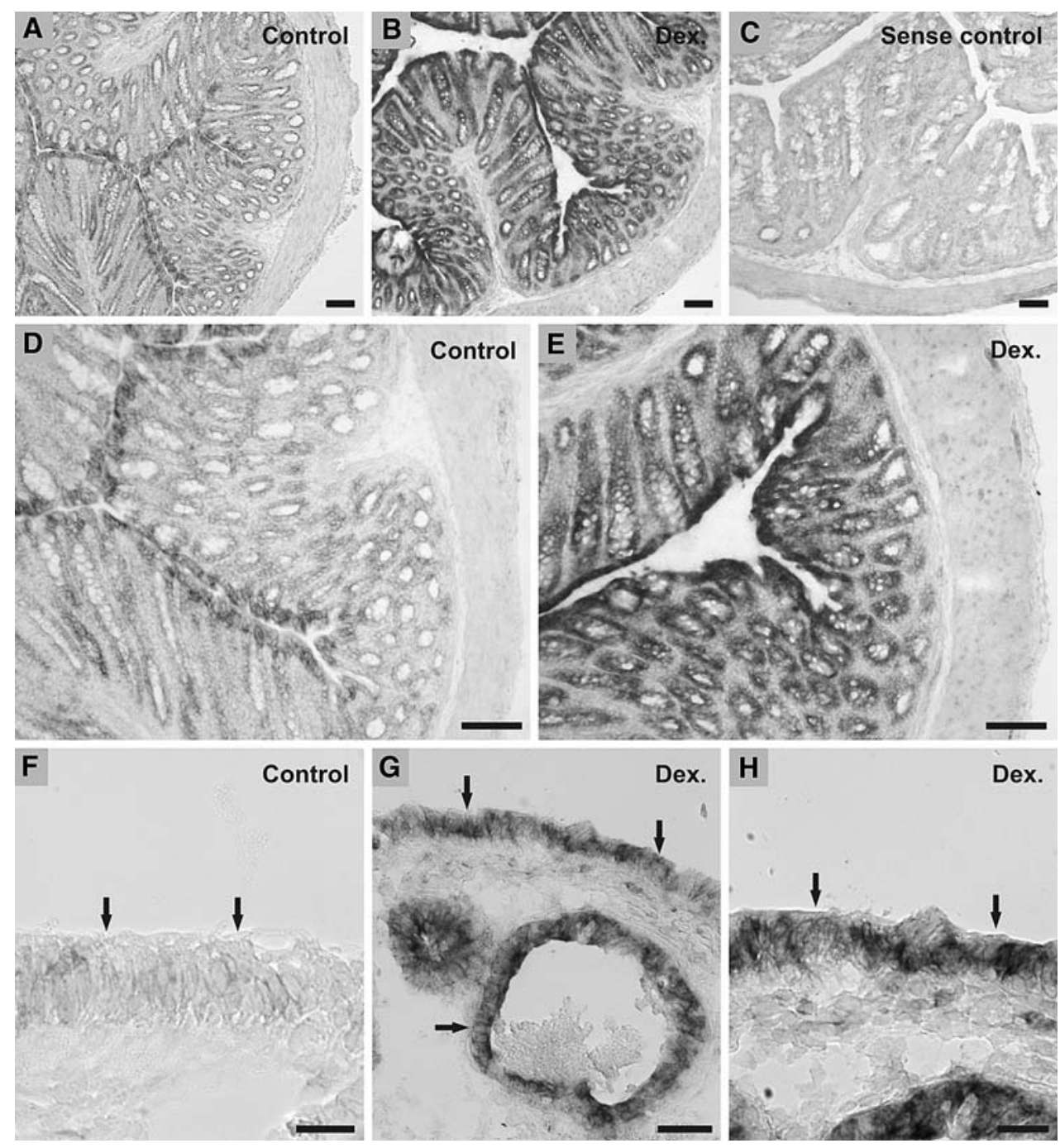
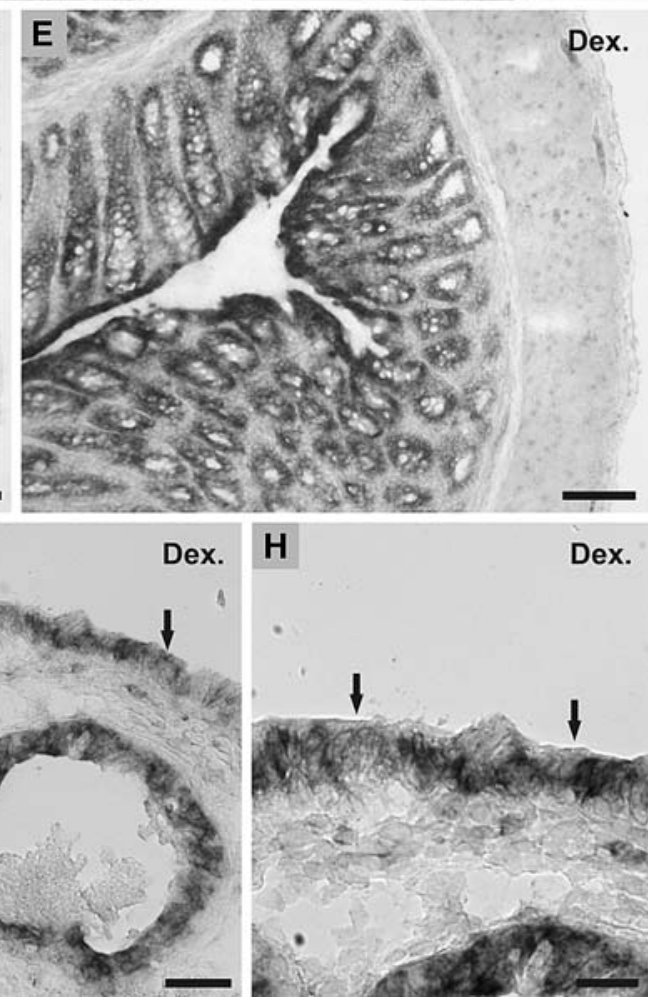


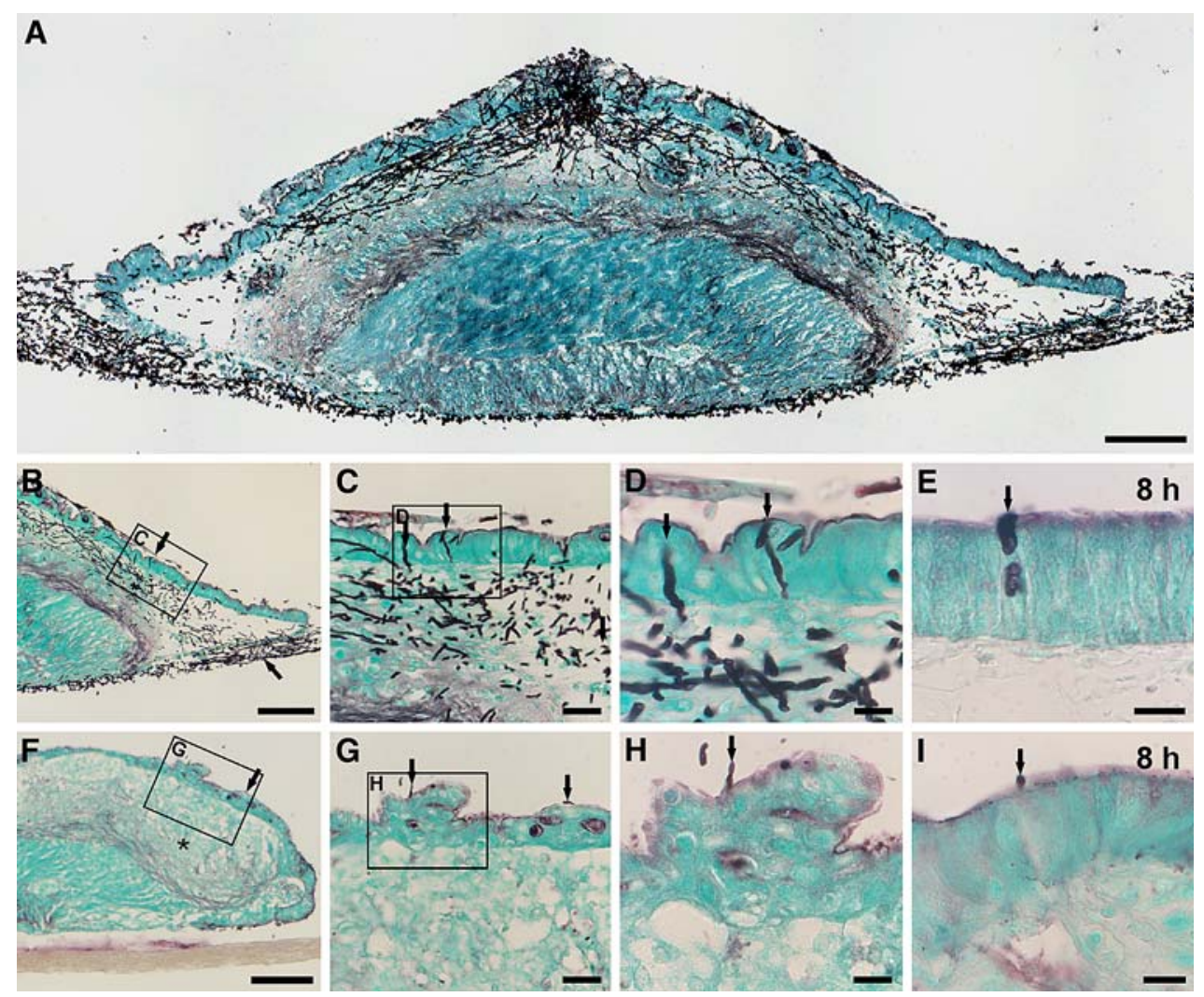

Fig. 5 Infection of the colonic tissue culture with the Candida albicans strains Can 14 (wildtype) and Can $34(\Delta \mathrm{cph} 1 / \Delta \mathrm{efg} 1)$ for 8 and $24 \mathrm{~h}$. Paraffin sections were stained according to the Grocott protocol. Note: In contrast to the weakly stained epithelial mucous and extracellular compounds (asterisk) inside the tissue culture, $C$. albicans cells showed distinguishable and strongly positive signals. a Overview of a paraffin cross-section from tissue culture incubated with Can 14 for $24 \mathrm{~h}$. b-d Different magnifications of the section from tissue culture $24 \mathrm{~h}$ after infection with Can 14 . The rectangle in $\mathbf{b}$ represents the area

in investigating mechanisms of intestinal infection under in vivo-like conditions.

\section{Discussion}

In the present study, we introduced an organotypical explant culture model from the adult mouse colon for the investigation of cell-cell interactions in a three-dimensional cell arrangement.

The tissue of our in vitro model was cultivated on membrane inserts at the interface between air and culture medium to ensure adequate in vitro nutrition and oxygen supply (Metzger et al. 2007). After cellular reorganization during the first week, the cultures were covered by a highprismatic epithelium similar to that found in vivo. After 6 days in vitro, these epithelial cells also possessed typical junctional complex and microvilli at their apical surface. At this point, BrdU-labeling experiments demonstrated prolif- magnified in c. The rectangle in $\mathbf{c}$ represents the area magnified in $\mathbf{d}$. Arrows point to penetrating fungal cells. e Can 14 infection after $8 \mathrm{~h}$. The arrow indicates a penetrating Candida cell. $\mathbf{f}-\mathbf{i}$ Infection experiments with the mutant Can 34, which is unable to penetrate the epithelium. $\mathbf{f}-\mathbf{h}$ Different magnifications of sections from tissue culture $24 \mathrm{~h}$ after infection with Can 34 . The rectangle in $\mathbf{f}$ represents the area magnified in $\mathbf{g}$. The rectangle in $\mathbf{g}$ represents the area magnified in $\mathbf{h}$. $\mathbf{i}$ Can 34 cells were incubated for $8 \mathrm{~h}$. The arrows point to cells at the culture surface. Scale bar $100 \mu \mathrm{m}$ in $\mathbf{a}, \mathbf{b}, \mathbf{f} ; 25 \mu \mathrm{m}$ in $\mathbf{c}, \mathbf{g} ; 10 \mu \mathrm{m}$ in $\mathbf{d}, \mathbf{e}, \mathbf{h}, \mathbf{i}$

erating epithelial cells at the surface of culture model. Differentiated goblet cells were identified by electron microscopy and Alcian blue staining. All the characteristic compounds of the epithelial barrier, such as epithelial cells, laminin-positive basal lamina and fibrocyte-like cells underneath the basal lamina, could be detected by immunohistochemistry and electron microscopy.

However, the regeneration capacity of epithelium declined within long-term culturing. This indicates that epithelial progenitor and stem cells differentiated and the stem cell compartment could not be maintained in vitro. For this reason, the cultures should be used between the first and second week in vitro to ensure a reliable quality of this tissue culture model.

Nevertheless, the reorganization processes during culturing make this model useful for investigating in detail the time-dependent cellular mechanisms and factors involved in epithelial regeneration and degeneration (e.g. growth factors, hormones, extracellular matrix compounds, cell-cell 
interactions with non-epithelial cells for a review see, de Santa Barbara et al. 2003; Marshman et al. 2002; Yen and Wright 2006). Additionally, the proposed culture model is suitable for implantation experiments to analyze the integration and differentiation capacity of grafted epithelial stem and tumor cells. Furthermore, re-implantation of these cultures into animal models could reveal whether epithelial stem cells of grafted tissue could be re-organized in stem cell niches in a three-dimensional environment in vivo.

In the past, several groups have used organotypical cultures of various gut regions and cultivated them either as free-floating cultures (Autrup 1980; DeRitis et al. 1975) or on different culture substrata in vitro (Altmann and Quaroni 1990; Quinlan et al. 2006; Schiff 1975). Alternatively, the chick chorioallantoic membrane (CAM) has been used to provide an in vivo-like environment (Burns 2005; Pomeranz and Gershon 1990). However, these techniques are basically restricted to embryonic tissues and are less suitable for experimental manipulations and real-time imaging.

A cultivation principle similar to that described for our model was published by Defries and Franks (Defries and Franks 1977). To our knowledge, this is the only group that has already analyzed intestinal explant cultures from adult mice in detail. However, in contrast to their culture method we used a different type of scaffold membrane and a different culture medium which was supplemented with adult horse serum instead of fetal calf serum.

Defries and Franks investigated the effect of donor age and carcinogen treatment on epithelial mitotic activity in their culture model.

Our aim was to establish a culture system of colonic mucosa for investigating the biological function of intestinal epithelium in an in vivo-like environment under normal and pathological conditions.

First, we evaluated the cell culture system by testing the known in vivo effect of dexamethasone on the gene expression of SGK1 in intestinal epithelial cells. Dexamethasone is a potent synthetic member of the glucocorticoid class of steroid hormones and acts as an anti-inflammatory and immunosuppressant drug. Glucocorticoids are involved in the regulation a variety of cellular processes in the mucosal intestinal epithelium such as cell proliferation und differentiation, activity of digestive enzymes, epithelial transport or intestinal first-pass metabolism (Binder et al. 1989; Quaroni et al. 1999).

In an earlier report we used in situ hybridization and real-time PCR to demonstrate that dexamethasone also stimulates SGK1 gene expression in the cells of the small intestine in vivo (Grahammer et al. 2006). SGK1 plays an important role in activating certain potassium, sodium and chloride channels and seems to be involved in the regulation of cell survival (for review see Lang and Cohen 2001). In the intestine of normal mice the SGK1 mRNA expres- sion of the epithelium was mainly located in differentiated epithelial cells at the surface of the gut wall. As in the small intestine, the SGK1 expression of colonic epithelial cells was strongly enhanced in mice treated with dexamethasone. And like in these in vivo experiments, the dexamethasone effect could be reproduced in epithelial cells of explant cultures.

To evaluate the suitability of our in vitro system for use as an infection model we performed infection experiments with wildtype and mutant strains of Candida albicans, a pathogen leading to systemic infections in immunocompromised patients (Cole et al. 1996; Darouiche 1998). The wild-type Candida (Candida 14) adhered to the epithelial surface and infiltrated the tissue. In contrast, the mutant strain (Candida 34) lacking the transcription factors EFG1 and $C P H I$ (Dieterich et al. 2002) was neither able to adhere to the epithelium, nor to penetrate the epithelial barrier in our in vitro model. The results are comparable to those from studies published by Dieterich et al. 2002. In these experiments, the same Candida strains were investigated in a three-dimensional intestinal in vitro model based on the colonic human cell line Caco- 2 co-cultured with human intestinal fibroblasts embedded in collagen I matrix. Threedimensional culture techniques with immortalized epithelial cell lines have also been used in infection experiments with Salmonella typhimurium (Honer zu et al. 2006; Nickerson et al. 2001). The advantage of using immortalized cells is a high level of standardization and reproducibility. However, because of the specific physiology and the more complex cell organization in primary tissues, explant cultures may bear a closer resemblance to the in vivo situation.

We conclude that the proposed three-dimensional cultures from adult murine colon may provide a suitable in vitro model of the gut.

Acknowledgments This research was supported by the German Ministry of Education and Research (BMBF) under grant PTJ-BIO/ 0313328A and by the Peter und Traudl Engelhorn Stiftung. We would like to thank Diane Blaurock for her helpful comments on the manuscript. We are indebted to Dr. Karin Klingel for kindly providing the SGK1 plasmid.

\section{References}

Abud HE, Watson N, Heath JK (2005) Growth of intestinal epithelium in organ culture is dependent on EGF signalling. Exp Cell Res 303:252-262

Altmann GG, Quaroni A (1990) Behavior of fetal intestinal organ culture explanted onto a collagen substratum. Development 110:353-370

Autrup H (1980) Explant culture of human colon. Methods Cell Biol 21B:385-401

Autrup H, Barrett LA, Jackson FE, Jesudason ML, Stoner G, Phelps P, Trump BF, Harris CC (1978a) Explant culture of human colon. Gastroenterology 74:1248-1257 
Autrup H, Stoner GD, Jackson F, Harris CC, Shamsuddin AK, Barrett LA, Trump BF (1978b) Explant culture of rat colon: a model system for studying metabolism of chemical carcinogens. In Vitro $14: 868-877$

Binder HJ, McGlone F, Sandle GI (1989) Effects of corticosteroid hormones on the electrophysiology of rat distal colon: implications for $\mathrm{Na}^{+}$and $\mathrm{K}^{+}$transport. J Physiol 410:425-441

Burns AJ (2005) Migration of neural crest-derived enteric nervous system precursor cells to and within the gastrointestinal tract. Int J Dev Biol 49:143-150

Cole GT, Halawa AA, Anaissie EJ (1996) The role of the gastrointestinal tract in hematogenous candidiasis: from the laboratory to the bedside. Clin Infect Dis 2:S73-S88

Darouiche RO (1998) Oropharyngeal and esophageal candidiasis in immunocompromised patients: treatment issues. Clin Infect Dis 26:259-272

De Santa Barbara P, van den Brink GR, Roberts DJ (2003) Development and differentiation of the intestinal epithelium. Cell Mol Life Sci 60:1322-1332

Defries EA, Franks LM (1977) An organ culture method for adult colon from germfree and conventional mice: effects of donor age and carcinogen treatment on epithelial mitotic activity. J Natl Cancer Inst 58:1323-1328

DeRitis G, Falchuk ZM, Trier JS (1975) Differentiation and maturation of cultured fetal rat jejunum. Dev Biol 45:304-317

Dieterich C, Schandar M, Noll M, Johannes FJ, Brunner H, Graeve T, Rupp S (2002) In vitro reconstructed human epithelia reveal contributions of Candida albicans EFG1 and CPH1 to adhesion and invasion. Microbiology 148:497-506

Finney KJ, Ince P, Appleton DR, Sunter JP, Watson AJ (1986) A comparison of crypt-cell proliferation in rat colonic mucosa in vivo and in vitro. J Anat 149:177-188

Firestone GL, Giampaolo JR, O'Keeffe BA (2003) Stimulus-dependent regulation of serum and glucocorticoid inducible protein kinase (SGK) transcription, subcellular localization and enzymatic activity. Cell Physiol Biochem 13:1-12

Grahammer F, Henke G, Sandu C, Rexhepaj R, Hussain A, Friedrich B, Risler T, Metzger M, Just L, Skutella T, Wulff P, Kuhl D, Lang $\mathrm{F}$ (2006) Intestinal function of gene-targeted mice lacking serumand glucocorticoid-inducible kinase 1. Am J Physiol Gastrointest Liver Physiol 290:G1114-G1123

Grocott RG (1955) A stain for fungi in tissue sections and smears using Gomori's methenamine-silver nitrate technic. Am J Clin Pathol 25:975-979

Heyman M (2005) Gut barrier dysfunction in food allergy. Eur J Gastroenterol Hepatol 17:1279-1285

Honer zu BK, Ramamurthy R, Ott CM, Emami K, Nelman-Gonzalez M, Wilson JW, Richter EG, Goodwin TJ, Alexander JS, Pierson DL, Pellis N, Buchanan KL, Nickerson CA (2006) Three-dimensional organotypic models of human colonic epithelium to study the early stages of enteric salmonellosis. Microbes Infect 8:1813-1825

Howdle PD (1983) Organ culture in the study of the gastrointestinal tract in health and disease. Clin Sci (Lond) 65:105-110
Lang F, Cohen P (2001) Regulation and physiological roles of serumand glucocorticoid-induced protein kinase isoforms. Sci STKE 2001:RE17

Lang F, Bohmer C, Palmada M, Seebohm G, Strutz-Seebohm N, Vallon V (2006) (Patho)physiological significance of the serum- and glucocorticoid-inducible kinase isoforms. Physiol Rev 86:11511178

Marshman E, Booth C, Potten CS (2002) The intesinal epithelial stem cell. Bioessays 24:91-98

Menard D, Arsenault P (1987) Human fetal colon in organ culture. Anat Embryol (Berl) 176:441-448

Metzger M, Bareiss PM, Nikolov I, Skutella T, Just L (2007) Threedimensional slice cultures from murine fetal gut for investigations of the enteric nervous system. Dev Dyn 236:128-133

Moorghen M, Chapman M, Appleton DR (1996) An organ-culture method for human colorectal mucosa using serum-free medium. J Pathol 180:102-105

Mothes T, Muhle W, Muller F, Schmidt W (1985) Chicken fetal intestine in tissue culture. Biomed Biochim Acta 44:561-571

Nickerson CA, Goodwin TJ, Terlonge J, Ott CM, Buchanan KL, Uicker WC, Emami K, LeBlanc CL, Ramamurthy R, Clarke MS, Vanderburg CR, Hammond T, Pierson DL (2001) Three-dimensional tissue assemblies: novel models for the study of Salmonella enterica serovar Typhimurium pathogenesis. Infect Immun 69:71067120

Pomeranz HD, Gershon MD (1990) Colonization of the avian hindgut by cells derived from the sacral neural crest. Dev Biol 137:378-394

Quaroni A, Tian JQ, Goke M, Podolsky DK (1999) Glucocorticoids have pleiotropic effects on small intestinal crypt cells. Am J Physiol 277:G1027-G1040

Quinlan JM, Yu WY, Hornsey MA, Tosh D, Slack JM (2006) In vitro culture of embryonic mouse intestinal epithelium: cell differentiation and introduction of reporter genes. BMC Dev Biol 6:24

Romeis B (1968) Histologische Technik, 16th edn. Oldenbourg Verlag, Muenchen

Rowlands BJ, Soong CV, Gardiner KR (1999) The gastrointestinal tract as a barrier in sepsis. Br Med Bull 55:196-211

Schiff LJ (1975) Organ cultures of rat and hamster colon. In Vitro 11:46-49

Shamsuddin AK, Barrett LA, Autrup H, Harris CC, Trump BF (1978) Long-term organ culture of adult rat colon. Pathol Res Pract 163:362-372

Trier JS (1976) Organ-culture methods in the study of gastrointestinalmucosal function and development. N Engl J Med 295:150-155

Venable JH, Coggeshall R (1965) A simplified lead citrate stain for use in electron microscopy. J Cell Biol 25:407-408

Waldegger S, Klingel K, Barth P, Sauter M, Rfer ML, Kandolf R, Lang $\mathrm{F}$ (1999) h-sgk serine-threonine protein kinase gene as transcriptional target of transforming growth factor beta in human intestine. Gastroenterology 116:1081-1088

Yen TH, Wright NA (2006) The gastrointestinal tract stem cell niche. Stem Cell Rev 2:203-212 